\title{
Oliver Ellsworth's Calvinism: A Biographical Essay on Religion and Political Psychology in the Early Republic
}

\author{
WLLIAM CASTO
}

The year 1801 was a catastrophe for staunch Federalists. Thomas Jefferson became president, and a coalition opposed to the Federalists gained control of the Congress. In New England, Standing Order Calvinist ministers hysterically railed that Jefferson was "a debaucher, an infidel, [and] a liar." 1 But one of New England's most prominent Federalists was more philosophical. Oliver Ellsworth, the third chief justice of the United States, was almost relieved that the Federalists would no longer have to try to make the national government work. Invoking the legend of Sisyphus, Ellsworth wrote, "So the anti-Feds are now to support their own administration, and take a turn at rolling stones up hill.",2 At first glance, this imagery seems a common example of the eighteenth-century political elite's use of classical metaphors. This author has come to believe, however, that biblical revelation illuminated by a thoroughgoing Calvinism was the primary philosophical influence in Ellsworth's life. This essay will explore the influence of Calvinism upon Ellsworth's understanding of political psychology, and incidentally will suggest that for Ellsworth the legend of Sisyphus was essentially a Calvinist allegory.

- WILLIAM CASTO (A.B., J.D., University of Tennessee: J.S.D., Columbia University) is professor of law at Texas Tech University School of Law. He is author of The Supreme Court in the Early Republic: The Chief Justiceships of John Jay and Oliver Ellsworth (forthcoming). His articles have appeared in American Journal of Legal History, Constitutional Commentary, Tulane Law Review, and American Joumal of International Law, among others. Special interests include federal courts, foreign affairs, and jurisprudence, all in the early republic. This article is part of a long-term project that will culminate in a full biography of Oliver Ellsworth.

1. Stephen Berk, Calvinism Versus Democracy (Hamden, Conn.: Archon Books, 1794), 156, quoting a contemporary newspaper article. See also Edwards Park, Memoir of Nathaniel Emmons (Boston, Mass.: Congregational Board of Publication, 1861), 138-42, discussing Emmons' Jeroboam Sermon in which Emmons compared John Adams to Solomon and the recently elected Jefferson to the infidel Jereboam.

2. Oliver Ellsworth to Rufus King, 21 January 1801, Huntington Library, San Marino, California. 
Most studies of Calvinism in eighteenth-century America have concentrated almost exclusively on the sermons and theology of $\mathrm{Cal}$ vinist ministers. ${ }^{3}$ Rather than reprise these valuable studies, this essay follows a different course and looks at Calvinism in the thoughts and actions of Oliver Ellsworth, an influential political figure and layman. Ellsworth is an obscure person to twentieth-century Americans even to historians. ${ }^{4}$ But he was well known and highly regarded in the early Republic. For example, Ellsworth was an influential participant in the drafting and ratification of the Federal Constitution and was the principal author of the Judiciary Act of 1789 . He subsequently led the Federalist forces in the Senate of the United States and completed his national service as the third chief justice of the United States.

Ellsworth was a New England Calvinist who was born into a New Light family in the aftermath of the Great Awakening. As a young man he personally experienced salvation through God's election and made a public profession of his regeneration. ${ }^{5}$ Throughout his life he cleaved to the unforgiving doctrines of the New Divinity theology that dominated Connecticut and adjacent parts of New England in the late eighteenth century.

Ellsworth's Calvinism is reflected in many facets of his public life. For example, his idea of the proper relationship between church and state was little more than a restatement of the Connecticut Standing Order Clergy's annual election sermons. ${ }^{6}$ In addition, a stringent doctrine of predestination informed his initial enthusiasm for, and ulti-

3. See, for example, the excellent treatments in Ruth Bloch, Visionary Republic (New York: Cambridge University Press, 1985); Nathan Hatch, The Sacred Cause of Liberty (New Haven, Conn.: Yale University Press, 1977); Harry Stout, The New England Soul (New York: Oxford University Press, 1986); and James Kloppenberg, "Christianity, Republicanism, and Ethics in Early American Political Discourse," Journal of American History 74 (1987): 9. 4. "There is no adequate biography of Oliver Ellsworth." The Documentary History of the Ratification of the Constitution, ed. Merrill Jensen (Madison, Wisc.: State Historical Society of Wisconsin, 1978), 3:337. The only full-scale biography was written in 1905: William Brown, The Life of Oliver Ellsworth (New York: Da Capo Press, 1970; originally published 1905).

5. Henry Rowland, A Sermon Occasioned by the Death and Delivered at the Funeral of the Honorable Oliver Ellsworth (Hartford, Conn.: William Sawyer \& Co., 1808), 12. Ellsworth's church records indicate that he became a member in full communion at age 23 in 1768. Mss: Church Book of the North Windsor Congregational Church, 1761-1794, Connecticut State Library, Hartford, Conn., 31. Only individuals who had professed a regenerating experience were entitled to full communion; p. $31 \mathrm{fn}$. and pp. 44-45.

6. See notes 79-101 herein and accompanying text. Because election sermons have cumbersome titles, I have adopted a short citation form that provides only the author's surname, the date, and the Evans or Shaw-Shoemaker number. All citations are to the sermon's pagination as originally published except for Bellamy's and Smalley's sermons that appear in Joseph Bellamy, The Works of Joseph Bellamy, 2 vols., ed. Tryon Edwards (Boston, Mass.: Doctrinal Tract and Book Society), 1:577-96; and John Smalley, Sermons on Various Topics Doctrinal and Practical (Middletown, Conn.: Hart \& Lincoln, 1814), 7-36. 
mate disenchantment with, the new federal government. ${ }^{7}$ At a more general level, original sin prefigured his understanding of the primary problem confronting government, ${ }^{8}$ and he used the Calvinist ideal of a "righteous ruler" to define the general obligations of government officials. ${ }^{9}$

\section{Public Service and the Righteous Ruler}

In the middle of the eighteenth century during Ellsworth's youth, the concept of public service was imbued with millennarianism. In 1758, Joseph Bellamy, a leading Connecticut Calvinist, delivered a powerful message of millennarianism and the role of the Church Militant in preparing the way for Christ's rule on earth. ${ }^{10} \mathrm{He}$ urged that true Christians should not passively await the Millennium when Satan would be bound and Christ would rule for a thousand years. He urged them to join the Church Militant:

It therefore becomes all the followers of Christ, in their several spheres, and a firm belief of these things, to be of good courage, and exert themselves to the utmost, in the use of all proper means to suppress error and vice of every kind, and promote the cause of truth and righteousness in the world; and so be workers together with God.11

In the concluding portion of the sermon, Bellamy wrote with a sense of urgency: "The time of the last general battle draws on, when a glorious victory is to be won; and . . the army [of God] shall drive all before them at last."12

Four years later Bellamy returned to this theme in a significant election sermon. ${ }^{13}$ He reminded the Connecticut General Assembly that when nations become righteous, the Millennium would be at hand: "Heaven would soon begin on earth."14 He emphasized the need for righteous rulers who would "promote a universal [religious] reformation" 15 and thereby herald the advent of Christ's rule. This idea that righteous rulers would in some way effect or signal the longed-for commencement of Christ's rule was a powerful message and undoubtedly had a significant impact upon young Oliver Ellsworth. Shortly after Bellamy delivered his sermon on The Millennium, Ellsworth boarded as a student with Bellamy in preparation for enter-

7. See notes $72-78$ and accompanying text.

8. See notes $45-52$ and accompanying text.

9. See notes 17-44 and accompanying text.

10. Joseph Bellamy, "The Millennium," in Bellamy's Works, 1: 443-61.

11. Ibid., 459.

12. Ibid.

13. Joseph Bellamy, "An Election Sermon," in Bellamy's Works, 1: 577-96.

14. Ibid., 582.

I5. Ibid., 587; see generally, 587-96. 
ing Yale College. Young Ellsworth entered Yale just a few months after Bellamy delivered his election sermon.

In retrospect, those who eagerly anticipated the immediate arrival of the Millennium were doomed to disappointment as the years passed and the anticipated event failed to transpire. This process of attenuation probably happened to Ellsworth. None of his extant writings look forward to the Millennium. Nevertheless, despite this inevitable attenuation, millennarianism persisted in North America throughout the eighteenth century and into the next. ${ }^{16}$

In addition to motivating conduct, millennarianism played a significant definitional role. The ideal of a ruler was defined at the outset of Ellsworth's life as an active participant in public affairs who is consciously motivated by Calvinist values. Thus, the definition created general categories of proper and improper conduct. To the extent that Calvinist leaders like Ellsworth wished to view themselves and be viewed as proper government officials, they would have been constrained to conform to these categories.

Millennarianism may have lent an air of urgency to the political process in the middle of the century and certainly provided a general definition of political leadership that emphasized activism. But the Golden Rule in the Book of Matthew provided more abiding encouragement and guidance for participation in government. From the middle of the century to the end, there was clear agreement among Connecticut Calvinists that the proper role of a good ruler was dictated by biblical revelation.

In Bellamy's 1762 election sermon, he reduced all moral virtue to compliance with the two prime commandments from the Book of Matthew: "Thou shalt love the Lord thy God with all thy heart [and] Thou shalt love thy neighbor as thyself."17 He equated virtue with righteousness and expected secular rulers to be righteous. Bellamy exalted the righteous ruler because he attains "his high station merely on account of his merit [and therefore] is the wisest man in the province, and a father to all his subjects."18 As required by God's command to love thy neighbor, "all the influence his high station, superior wisdom, and goodness give him over [his subjects'] hearts, is wholly consecrated to make them a still holier and happier people."19 Bellamy likened this duty to serve the people to that of "a nursing father or mother towards

16. See Bloch, Visionary Republic, 17; Hatch, The Sacred Cause of Liberty.

17. Bellamy, "Election Sermon," in Bellamy's Works, 1:578-79, quoting and explaining Matt. 22:37 \& 40; see also Joseph Bellamy, "True Religion Delineated," in Bellamy's Works, 1:13-14.

18. Bellamy, "Election Sermon," 1:584.

19. Ibid. 
an infant child."20 In contrast, sinful rulers are guilty of self-love. They "have no fear of God before their eyes, or regard to the public weal, and act an arbitrary and tyrannical part."21

Bellamy's emphasis upon the Book of Matthew and his explication of the righteous ruler were together a continuing article of faith among Connecticut Calvinists. At the beginning of the nineteenth century, the Connecticut Missionary Society published A Summary of Christian Doctrine that reiterated the primacy of the Book of Matthew. ${ }^{22}$ By this time Ellsworth was a leading member of Connecticut's Standing Order, a member of the Society's Board of Directors, and a lay member of the nine-person committee that wrote the Summary. ${ }^{23}$ Although the absolute duty to love thy neighbor had become subtly attenuated, ${ }^{24}$ the duties of a ruler remained unchanged: "The Bible . . . teaches [that a ruler should do] whatever is essential to the common weal."25 Therefore rulers must "prefer . . . the true interest of the state to any partial interest." 26 In particular, a public official's duty consisted "in providing good laws-in distributing impartial justice to the rich and to the poor-in protecting all in their rights and guarding the common interest and safety."27

The ideal of a righteous ruler is in many ways similar to the concept of republican virtue. We are told, however, that republican virtue was a secular notion that eighteenth-century Americans derived either directly or indirectly from the classical Greeks and Romans. The values of secular or classical republicanism undoubtedly were embedded in eighteenth-century New England political culture, but to emphasize this secular strand of thought ignores the realities of Calvinist culture. ${ }^{28}$ The Calvinist clergy were aware of classical republicanism ${ }^{29}$ and probably were influenced by it. But they explained their ideal of a righteous

20. Ibid.

21. Ibid., 586.

22. Missionary Society of Connecticut, A Summary of Christian Doctrine and Practice: Designed Especially, for the use of the People in the New Settlement of the United States of America (Hartford, Conn.: Hudson \& Goodwin, 1804), chap. 18.

23. This tract was written by a nine-person committee consisting of seven Standing Order ministers, the state's lieutenant governor, and Oliver Ellsworth, the state's best known and most respected participant in national politics. Mss: "Second Book of Records of the Trustees of the Missionary Society of Connecticut, 1802-1822," United Church Center, Hartford, Conn., 25.

24. See Summary of Christian Doctrine, chap. 19.

25. Ibid., ch. 20, para 3.

26. Ibid.

27. Ibid.

28. See Stout, The New England Soul, 364, fn. 64.

29. See, e.g., Goodrich's Election Sermon (1789), 21-22 (Evans no. 20393); Backus's Election Sermon (1793), 9-10 (Evans no. 25130); Lee's Election Sermon (1795), 10-11 (Evans no. 28957); Lewis's Election Sermon (1797) 13 (Evans no. 32377). "Machiavellian 
ruler exclusively in terms of biblical revelation, and they taught their fellow Calvinists that the ideal of a righteous ruler was dictated by the word of God. ${ }^{30}$ Given their Calvinist faith in a world minutely predestined by an omnipotent God, the clergy could hardly explain such a key concept as being founded on the non-biblical writings of heathen Greeks and Romans.

In addition to premising the concept of a righteous ruler exclusively upon the revealed word of God, Calvinists explicitly rejected secular virtue as à viable foundation for government. ${ }^{31}$ The classical ideal was fundamentally in conflict with the core Calvinist doctrines of original sin and election. Since human beings are inherently depraved, they have an inherent disability to conduct themselves according to the honorable rules found in the classics. The only hope of rising above this congenital depravity is through God's intervening election and bestowal of grace. Honor without election is little more than a facade that masks self-love and depravity. ${ }^{32}$ The Calvinist clergy were quite explicit in warning people to beware of individuals who professed to be virtuous but who did not have a righteous love of God and fellow man. The simple truth was that such an individual could not be trusted to eschew sinful self-interest. ${ }^{33}$ In contrast, a righteous ruler who had experienced God's grace understood the awesome significance of appearing before God on judgment day.

Joseph Perry, Ellsworth's friend and neighbor, succinctly explained the matter in his 1775 election sermon:

principles" were criticized in Wales's Election Sermon (1785), 18 (Evans no. 19359), and Lee's Election Sermon (1795), 13-14 (Evans no. 28957).

30. See notes 9-18 and accompanying text. Accord Whittelsey's Election Sermon (1778), 9-11 (Evans no. 16170); Dana's Election Sermon (1779), 13; Robbins' Election Sermon (1789), 12-20 (Evans no. 22118); N. Strong's Election Sermon (1790), 6-13 (Evans no. 22913); Dwight's Election Sermon (1791), 15-18 (Evans no. 23341); Backus's Election Sermon (1793), 9-17 (Evans no. 25130); Trumbull's Election Sermon (1801), 17-22 (ShawShoemaker no. 1440); Bassett's Election Sermon (1807), 26.

31. See Perry's Election Sermon (1775), 14-15 (Evans no. 14383); Whittelsey's Election Sermon (1778) 10 (Evans no. 16170); Stiles's Election Sermon (1783), 78-87 (Evans no. 18198); N. Strong's Election Sermon (1790), $11-14$ (Evans no. 22913); Dwight's Election Sermon (1791), 14-17 (Evans no. 23341); Stone's Election Sermon (1792), 23-25 (Evans no. 24820); Edwards's Election Sermon (1794) (Evans no. 26934); Marsh's Election Sermon (1796), 12-14 (Evans no. 30738); Smalley's Election Sermon (1800), 27-28, 30; Hooker's Election Sermon (1805), 13-20 (Shaw-Shoemaker no. 8635); Bassett's Election Sermon (1807), 24. These sermons are consistent with Nathan Hatch's general discussion of the relationship between Christian virtue and politics. Hatch, The Sacred Cause of Liberty, ch. 4.

32. Dwight's Election Sermon (1791), 21-22 (Evans no. 23341).

33. Strong's Election Sermon (1790), 13-14 (Evans no. 22913); Dwight's Election Sermon (1791), 13-15, 21-26 (Evans no. 23341); Edwards's Election Sermon (1794) (Evans no. 26934); Marsh's Election Sermon (1796), 12-13 (Evans no. 30738). 
Other principles, such as honor, public spirit, natural benevolence, and ambition, it is true, in some instances have influenced men to do many worthy deeds for the happiness of the community they stood related to-many among the Greeks and Romans, from these principles, displayed noble instances of patriotism.-But such are not so sure, nor do they bind in the same way, nor to the same degree, as principles of religious virtue.-The good man has his mind impressed with a sense of future invisible objects-he lives and acts under a sense of the omniscient eye of God, remembers the solemn account we must give and the reward he shall receive for his conduct. ${ }^{34}$

Thus the Calvinist clergy.

As a young man Ellsworth was imbued with this ideal of a righteous ruler, and he formally subscribed to it in his old age. More important, the ideal is omnipresent in his private and public writings. His series of essays urging ratification of the proposed Constitution of 1787 are illustrative. ${ }^{35}$ True to the Calvinist model, he persistently attacked opponents of the Constitution as selfish men bent on private gain. ${ }^{36}$ In contrast he urged the need for virtue in public affairs. ${ }^{37}$ Echoing Bellamy's Election Sermon, ${ }^{38}$ he predicted that the people's representatives in the national government would be "honest and wise." 39 Similarly, he stated on other occasions that righteous rulers were personally selected to their positions by God and accordingly entitled to respect as God's agents on earth. ${ }^{40}$

34. Perry's Election Sermon (1775), 14-15 (Evans no. 14383). Accord, Whittelsey's Election Sermon (1778), 11, 14 (Evans no. 16170); Strong's Election Sermon (1790), 9-18 (Evans no. 22913); Dwight's Election Sermon (1791), 13-24 (Evans no. 23341); Edwards's Election Sermon (1794) (Evans no. 26934); Marsh's Election Sermon (1796), 11-16 (Evans no. 30738); Strong's Election Sermon (1802), 11-13 (Shaw-Shoemaker no. 3124); Burnet's Election Sermon (1803), 6-10 (Shaw-Shoemaker no 3919); Hooker's Election Sermon (1805), 13-20 (Shaw-Shoemaker no. 8635). Various sermons by Timothy Dwight (President of Yale College from 1795-1817) on this theme are analyzed and discussed in William Dennis, "The Federalist Persuasion: The American Ideal of the Connecticut Federalists," Ph.D. diss., Yale University, 1971, 36-42; Hatch, The Sacred Cause of Liberty, 105-09.

35. Oliver Ellsworth, "The Letters of a Landholder," in Essays on the Constitution of the United States, ed. Paul Ford (New York: Burt Franklin, 1970; originally published 1892).

36. "Landholder I," 139; "Landholder II," 149, "Landholder VI," 162; "Landholder VII," 170; "Landholder VIII," 176.

37. "Landholder XII," 198; "Landholder XIII," 200.

38. See notes 18-19 and accompanying text.

39. "Landholder IV," 152.

40. Senator Maclay reports that in Senate debate on the subject of titles, "Ellsworth . . . got on the subject of Kings. Declared that the Sentence in the Primer of Fear God and honor King was of great importance that Kings were of divine appointment, that Saul the head \& shoulders taller than the rest of the people was elected by God and anointed by his appointment." William Maclay, The Diary of William Maclay and Other Notes on Senate Debates, ed. Kenneth Bowling and Helen Veit, Documentary History of the First Federal Congress of the United States (Baltimore, Md.: Johns Hopkins University Press, 1988), 9:27 (emphasis original to indicate quote from New Testament, 1 Peter 2:17). This idea that rulers were appointed by God was a common theme among Connecticut Calvinists. See Mather's Election Sermon (1781), 6-9, 14 (Evans no. 17236); Whitney's Election Sermon 
These clear parallels to the Calvinist concept of a righteous ruler were not coincidental similarities between independent secular and religious ideals. Ellsworth occasionally used the overtly religious idea of "unrighteousness" to describe the selfish schemes of men who lack virtue. ${ }^{41}$ Similarly, he argued in the Connecticut Ratification Convention that an "efficient" federal government would promote "justice and righteousness." 42 Likewise, he directly linked the problem of selfish rulers with the prevailing tenets of New England Calvinism when he warned against a hypothetical "unprincipled man, who believes neither the word nor the being of God; and [is] governed merely by selfish motives." 43 This warning is simply a restatement of fundamental religious doctrine that equated all virtue with a love of God and neighbor and specified selfishness as the basis of all sin. ${ }^{44}$

\section{Original Sin as an Obstacle to Good Government}

One of the primary obstacles to good government by righteous rulers was inherent in the people's basic character. In 1790, Nathan Strong, Ellsworth's former minister in Hartford, noted that "human nature must be taken by the civil governor as he finds it." 45 Ten years later while serving as peace commissioner to France, ${ }^{46}$ Ellsworth explained his understanding of human nature in a revealing conversation with the Comte de Volney, a French philosopher. After Volney out-

(1788), 8-9 (Evans no. 21601); Strong's Election Sermon (1790), 20 (Evans no. 22913); Ely's Election Sermon (1804), 29 (Shaw-Shoemaker no. 6243); Hooker's Election Sermon (1805), 21 (Shaw-Showmaker no. 8635); Trumbull's Election Sermon (1801), 15 (Shaw-Shoemaker no. 1440). Accord, Samuel Finley, The Curse of Meroz; the Danger of Neutrality, in the Cause of God, and our Country (Philadelphia: James Cattin, 1757), 10 (Evans no. 7893). Finley was Ellsworth's teacher at Princeton. The astonishing reference to the divine right of kings should not be taken literally. If Ellsworth was a monarchist who believed in the divine right of kings, he surely would not have publicly espoused that doctrine on the floor of the Senate in 1789. He simply was too shrewd a politician to commit such a gaffe. The more plausible explanation is that when Connecticut Calvinists used biblical verse to discuss government, they used "king" as a generic word to signify government. See Lee's Election Sermon (1795), 8 (Evans no. 28957) (explaining the usage). For other examples of the word King used in this generic sense, see Summary of Christian Doctrine ch. XX, para. 9; Ely's Election Sermon (1804), 34 (Shaw-Shoemaker no. 6243). This generic usage of a seemingly specific word may explain Thomas Paine's 1803 charge that Ellsworth was an avowed monarchist. See Thomas Paine to Elisha Babcock, 10 October 1803, in Yale University Library Gazette 30 (January 1956): 97-98.

41. "Landholder XII," 197. Accord, "Landholder V," 159 (warning of "jealousy and unrighteousness").

42. Oliver Ellsworth's speech of 7 January 1788; Jensen, Ratification Documents, 3:554.

43. "Landholder VII," 170.

44. See notes 17-34 and accompanying text.

45. Strong's Election Sermon (1790) (Evans no. 22913).

46. Ellsworth's mission was to negotiate a treaty concluding our undeclared naval war with France; see Alexander De Conde, The Quasi-War (New York: Scribner, 1966). 
lined a comprehensive plan for the government of post-revolutionary France, Ellsworth remarked, "there is one thing Mr. Volney for which you have made no provision ... The Selfishness of man."47 This pessimistic view of human nature was an enduring theme for Ellsworth. ${ }^{48}$ Among other things his pessimism led him to distrust democracy. ${ }^{49}$ Similarly he disliked the use of a random ballot to select juries because "a very ignorant Jury might be drawn by Ballot."50 His concern about the selfishness of man is little more than a restatement of the doctrine of original sin that pictured humankind as inherently depraved. ${ }^{51}$ Even the phraseology is taken from New Divinity Calvinism which defined sin exclusively in terms of selfishness. ${ }^{52}$

47. Oliver Ellsworth Papers, Bancroft Transcript, New York Public Library, 63. This portion of the Bancroft Transcripts was copied from a lengthy manuscript biography written by Ellsworth's son-in-law, Joseph Wood. In this manuscript biography, Volney is described as "the celebrated Infidel Philosopher."

48. See, for example, "Ellsworth's Charge to the Georgia Grand Jury," 25 April 1796 ("numerous are the vices, and as obstinate the prejudices, and as daring as restless the ambition, which perpetually hazard the national peace"), in The Documentary History of the Supreme Court of the United States, ed. Maeva Marcus (New York: Columbia University Press, 1990), 120; ibid., "Ellsworth's Charge to the South Carolina Grand Jury," 7 May 1799, in The Documentary History, 357-59. In an earlier political essay, Ellsworth condemned religious test oaths as "ineffectual . . . because men of loose principle will, by an external compliance, evade them." "Landholder VII," 170. Similarly one of his favorite polemical tactics in urging ratification of the Constitution was to charge his opponents with greed and corruption. See n. 35 and accompanying text.

49. For example, during the secret deliberations of the Philadelphia Convention, he argued in favor of senators being selected by the state legislatures because "Would not more [wisdom] flow from the Legislatures; than from an immediate election by the people." The Records of the Federal Convention of 1787, ed. Max Farrand (New Haven, Conn.: Yale University Press, 1937), 1:406 (Madison's Notes). Accord, 414 (Yates's notes).

50. William Laughton Smith to Edward Rutledge, 9 August 1789 (quoting Ellsworth), in South Carolina Historical Magazine 69 (1968): 23.

51. See Mss: "Bloomfield Congregational Church Records," Connecticut State Library, Hartford, Connecticut, 3:9-10 (Confession of Faith of Ellsworth's church when he lived in Bloomfield); Mss: "First Congregational Church of Windsor Records (1636-1932)," 15:39, Connecticut State Library, Hartford, Connecticut (Baptismal Covenant of Ellsworth's church in Windsor).

52. In his principal work, Joseph Bellamy contrasted selfishness with the primary tenets taken from the Book of Matthew (see n. 17 and accompanying text) when he wrote, "From this same root - this disposition to love ourselves supremely, live to ourselves ultimately, and delight in that which is not God wholly - proceeds all our evil carriage towards our neighbor." Joseph Bellamy, "True Religion Delineated," in Bellamy's Words, 1:150-51 (emphasis added). See also Summary of Christian Doctrine ch. XV, para. 1; and Joseph Conforti, Samuel Hopkins and the New Divinity Movement (Grand Rapids, Mich.: Christian University Press, 1981), ch. 7. 


\section{Order OUt of Chaos}

Ellsworth was, if anything, a conservative man who loved order and abhorred chaos. His grand jury charges are particularly instructive..$^{53}$ In his first charge as Chief Justice of the United States, he praised the national laws: "Tho' [these laws] pervade a country, as diversified in habits, as it is vast in extent, yet they give to the whole, harmony of interest, and unity of design." 54 In a subsequent charge he expressly drew the negative inference from his love of order. He attacked (almost hysterically) "the baleful influence of those elements of disorganization, \& tenets of impiety, which have been propagated with a zeal [by "discipled" individuals who] revolt . . . at every institution which can preserve order or protect right." 55

These feelings about order and chaos are the common, secular values of any man who has committed his life to working within the status quo and been richly rewarded for his efforts. But the desire for order and the fear of chaos also implicated religious doctrine at the core of Ellsworth's New Divinity theology. ${ }^{56}$ That an omnipotent God who has predestined all of history would ultimately prefer chaos to order was inconceivable. ${ }^{57}$ Furthermore, Ellsworth explicitly linked the fundamental problem of order and chaos to religion when he instructed grand juries that "national laws . . . are the means by which it pleases heaven to make of weak and discordant parts, one great people; and to bestow upon them unexampled prosperity."5s Conversely, he linked

53. The early Supreme Court justices viewed the grand jury charges as a valuable tool for instructing the nation on proper values; see Ralph Lerner, "The Supreme Court as Republican Schoolmaster," Supreme Court Review (1967): 127-80.

54. Ellsworth, "Charge to the Grand Jury of the Circuit Court for the District of Georgia," 25 April 1796, in Marcus, ed., Documentary History of the Supreme Court, 3:119.

55. "Ellsworth's Charge to the New York Grand Jury," 1 April 1797, in Documentary History, 3:158-60; see also "Ellsworth's Charge to the Georgia Grand Jury," 119 ("Let then, the ... men, who, from whatever motive, oppose partial to general will, and would disjoint their country to the sport of fortune, feel their [i.e., the partial men's] impotence and error.").

56. See generally Stephen Berk, Calvinism Versus Democracy (Hamden, Conn: Archon Books, 1974). For an analysis of seventeenth-century English Calvinists drawing similar conclusions, see Michael Walzer, The Revolution of the Saints (Cambridge, Mass: Harvard University Press, 1965).

57. See Bellamy's Election Sermon (1762), 582-88 (emphasizing the unity and order of a righteous nation and the disorder of a sinful nation). For the New England clergy's similar emphasis upon order in the 1790s, see Hatch, The Sacred Cause of Liberty, ch. 4.

58. "Ellsworth's Charge to the Georgia Grand Jury." See also "Landholder IX," 180, in which he warned, "Anarchy is a condition which mankind will not long endure. To avoid its distress they will resort to any standard which is erected, and bless the ambitious usurper as a messenger sent by heaven to save a miserable people." This passage suggests that there was such a strong link in Ellsworth's mind between religion and secular order that he assumed that even the false order of a tyrant would be linked to a presumably false religion. The passage also implicitly assumes the Calvinist notion of a righteous ruler by describing the usurper as "ambitious." A righteous ruler is motivated solely by concern for the com- 
"elements of disorder \& tenets of impiety" together ${ }^{59}$ and branded opponents of order as "impious." 60 This same desire for order is forcefully presented in a passage from A Summary of Christian Doctrine flatly pronouncing, "The design of all government is to make every one feel the relation in which he stands to the community, and to compel him to conduct as becomes that relationship."61

In addition to establishing the relative value of chaos and order, Ellsworth's religion provided a reassuring model for understanding and becoming reconciled to the persistence of chaos within society. In particular Ellsworth used an influential theodicy written by his teacher Joseph Bellamy to come to terms with the pervasive presence of chaos and sin in human society. Bellamy published The Wisdom of God in the Permission of Sin in 1758 immediately before Ellsworth entered his tutelage. The tract was a rigorously logical theodicy that remained ruthlessly true to Calvinist doctrine. The course of human events follows a perfect predestined plan conceived by a perfect God to craft the best possible world. This plan, however, is "as absolutely incomprehensible by us as it is by children of four years old."'62 Although the details are incomprehensible to finite and imperfect creatures, the broad outlines of God's plan were discernible to Bellamy: ${ }^{33}$ God in his infinite wisdom has decided that the permission of sin is the best method for instructing man in God's perfection and man's imperfection. Only individuals who thoroughly understand their sinfulness are fit to be saved by God. Bellamy's basic message, however, was optimistic. We should not be disheartened by the presence of evil in the world. To the contrary, sin is part of God's plan, and all will come right in the end. ${ }^{64}$

mon good and is not concerned with personal ambition. See notes 17-34 and accompanying text.

59. "Ellsworth's Charge to the New York Grand Jury," quoted in text accompanying n. 55.

60. Ibid.

61. Summary of Christian Doctrine, ch. 20, p. 54. Similarly, the catechism of Ellsworth's First Society in Windsor provided, "The fifth commandment requireth the preserving the honour, and performing the duties belonging to every one in their several places and relations, as superiors, inferiors or equals." Westminster Assembly of Divines, The Shorter Catechism, 1648, LXIV, adopted, Mss: "First Congregational Church of Windsor Records," (1636-1932), 15:37, Connecticut State Library, Hartford, Connecticut; see also ibid., LXXXI.

62. Joseph Bellamy, "The Wisdom of God in the Permission Sin," in Bellamy's Works, $2: 28$.

63. See Alan Heimert, Religion and the American Mind (Cambridge, Mass: Harvard University Press, 1966), 342-43; Frank Foster, A Genetic History of the New England Theology (Chicago, Ill: University of Chicago Press, 1907), 118-28.

64. Bellamy's express purpose in publishing the sermons on God's Wisdom was to urge the faithful of New England not to despair that "the state of the world and of the church appears so exceedingly gloomy and dark, and still darker times are by may expected." Bellamy, 
The influence of God's Wisdom is evident in a private letter ${ }^{65}$ written by Ellsworth in 1779 to Theodore Hinsdale, the minister of his church. Evidently Hinsdale had complained about the Revolutionary War's general impact upon the world's "moral State." Ellsworth, who was then serving in the Continental Congress, replied that he also was "waiting ... tho' perhaps with less concern and more doubt, to see [the impact of] the great events now taking place." Consistent with Calvinist theology, he added that he did not know "the design of Providence in this respect,"but he conceded that "the powers at war have very little design about [the world's moral state] and terminate their views with wealth and empire, leaving religion pretty much out of the question." He concluded these thoughts with a mild rebuke to his doubting minister. Restating the central theme of God's Wisdom, Ellsworth reminded Hinsdale that, "it is sufficient, dear Sir, that God governs the world, and that his purposes of Grace will be accomplished."

Some ten years later Ellsworth expressly referred to God's Wisdom and used Bellamy's theodicy to structure an argument urging Rhode Island to ratify the Constitution. ${ }^{66}$ During this period Rhode Island was anathema to creditors because the state had purposefully inflated its currency. ${ }^{67}$ Ellsworth predictably viewed this manipulation as an iniquity illustrating "the progress of human depravity." 68 Reasoning from Bellamy's theodicy, he argued:

Wisdom of God, 5 . He was referring to Catholic successes in the French and Indian Wars. See Alan Heimert and Perry Miller, The Great Awakening (Indianapolis, Ind: Bobbs-Merrill, 1967), 609. In the concluding sentence of the preface, Bellamy exhorted, "A firm belief of the supreme Godhead of our Saviour ... together with an insight into the nature and wisdom of God's universal government, way afford abundant support, let the present storm rise ever so high, and the time grow ever so dark." Bellamy, Wisdom of God, 5.

65. Oliver Ellsworth to Theodore Hinsdale, 26 January 1779, in Letters of Delegates to Congress, 1774-1789, ed. Paul Smith (Washington, D.C.: Library of Congress, 1985), 11:518-19. For a letter expressing similar sentiments, see Oliver Ellsworth to Jonathan Trumbull, 18 March 1780, in ibid., 14:548-49.

66. "Landholder XII," 196-99. Ellsworth ended the opening paragraph of this essay by expressly adopting God's Wisdom as a model: "The sentiment thrown out by some of our adventurous divines [i.e., Joseph Bellamy], that the permission of $\sin$ is the highest display of supreme wisdom, and the greatest blessing to the universe, is most successfully illustrated by the effects of your general policy." Ibid., 196 (emphasis added to note the paraphrasing of the original title of Wisdom of God). In this context, the adjective, "adventurous," was used to denote enterprising without the connotation of rashness. See The Oxford English Dictionary, I:A-137. For an earlier cameo version of "Landholder XII," see "Landholder V," 159.

67. See Jedidiah Morse, The American Geography (Elizabethtown, Mass: Shepard Kollock, 1789), 120-21. Ellsworth owned three copies of Morse's American Geography. Mss: "Inventory of the Estate of Oliver Ellsworth," 7, Connecticut State Library, Hartford, Connecticut.

68. "Landholder XII," 196. Connecticut's Standing Order clergy agreed. See Wales's Election Sermon (1785), 13-19 (Evans no. 19359); Hart's Election Sermon (1786), 22-23, 
In point of magnitude, your little state bears much the same proportion to the United American empire, as the little world doth to the immense intelligent universe; and if the apostasy of man hath conveyed such solemn warning and instruction to the whole, as your councils have to every part of the union, no one will doubt the usefulness of Adam's fall. ${ }^{69}$

As he implied, even Rhode Island's “depravity" was part of God's plan. "Heaven permitted [this] apostasy from all the principles of good and just government" to instruct the other members of the proposed union. ${ }^{70}$ Ellsworth concluded his essay by threatening "political annihilation" if Rhode Island did not mend its way. ${ }^{71}$

\section{The Possibility of National ORder}

In keeping with the optimism and faith of God's Wisdom, Ellsworth undoubtedly assumed that the Constitution that he helped to create was part of God's plan to bring a righteous order to the chaos of the Confederation. The Constitution was ratified, and George Washington - whom Connecticut Calvinists considered to be the ultimate righteous ruler - was elected president. But national politics quickly degenerated into sectional squabbles and a national rift between the Federalists and the Jeffersonian Republicans.

God's Wisdom initially provided Ellsworth with a flexible mindset for dealing with political strife. Even the wrongheaded faction lead by Jefferson could be viewed as part of God's plan. Moreover, Bellamy's theodicy based upon faith and optimism could easily be understood as permitting righteous rulers like Ellsworth to compromise their principles as long as they continued to believe that the country was moving in the right direction. In 1796 during a time of bitter political controversy

25-26 (Evans no. 19699); Whitney's Election Sermon (1788), 29 (Evans no. 21601); Dwight's Election Sermon (1791), 17 (Evans no. 23341).

69. "Landholder XII," 197.

70. Ibid. Accord, "Landholder," 159.

71. "Landholder XII," 199. Rhode Island initially refused to ratify the Constitution. See Memorial of the General Assembly of the State of Rhode Island and Providence Plantations (1789), in Records of the State of Rhode Island and Providence Plantation in New England, ed. John Bartlett (Providence, R.I.: Providence Press, 1865), 10:356-57. In response and under Ellsworth's leadership, the Senate passed the Rhode Island Trade Bill that would have suspended all trade between the United States and Rhode Island. See Documentary History of the First Federal Congress of the United States of America: Legislative Histories, ed. Charlene Bickford and Helen Viet (Baltimore, Md.: John Hopkins University Press, 1986), 6:1810-14. For Ellsworth's leadership in this matter, see Oliver Ellsworth to Mrs. Ellsworth, 7 June 1790, Oliver Ellsworth Papers, Connecticut Historical Society, Hartford, Connecticut. See also Maclay, Diary, 263. In response, Rhode Island ratified the Constitution. See Oliver Ellsworth to Mrs. Ellsworth, 7 June 1790, Oliver Ellsworth Papers, Connecticut Historical Society, Hartford, Connecticut. 
between the Federalists and the Jeffersonian Republicans, ${ }^{72}$ Ellsworth wrote his son-in-law, "Of politics I will converse with you when I come, and am satisfied in the meantime that God governs the world, \& will turn all the wrath \& folly of men to good account." 73 Five months later, Ellsworth still viewed the Federalists' plight in optimistic religious terms when he wrote his Calvinist friend, the governor of Massachusetts, "We may however yet hope that the gates of Hell will not prevail."74

But optimism is difficult to sustain in the face of repeated disaster. As Jefferson's faction grew stronger through the 1790's, Ellsworth came to doubt that the federal Constitution had created a path to righteous order. By the end of the century he was telling his fellow Federalists "that there is in a government like ours a natural antipathy to system of every kind."75 When Jefferson's coalition gained control of the national government in 1800, Ellsworth compared the task of governing under the Constitution to the legend of Sisyphus: "So, the Antifeds are now to support their own administration and take a turn at rolling stones up hill."76

The legend of Sisyphus would have been particularly appealing to a Calvinist like Ellsworth who believed generally in predestination and who believed specifically that governments were part of God's plan. In the legend, Sisyphus was a very clever ruler, and there are also suggestions that he was a knave and perhaps even a robber and murderer. In any event Sisyphus tricked and betrayed the gods. In response, and as an exemplary punishment, the gods doomed him to his eternal task.

The parallels between Jefferson and Sisyphus are clear. Both men were clever rulers. Moreover, New England Calvinists saw Jefferson as a man who had betrayed God. By suggesting that Jefferson was as cer-

72. See John Miller, The Federalist Era (New York: Harper \& Row, 1960), ch. 10-11. See also Oliver Ellsworth to George Washington, 19 June 1796, George Washington Papers, Library of Congress; Oliver Ellsworth to Caleb Strong, 25 October 1796, Caleb Strong Papers, Forbes Library, Northampton, Massachusetts, quoted in text accompanying n. 74 .

73. Oliver Ellsworth to Ezekiel Williams Jr., 29 May 1796, Ezekiel Williams Papers, Trinity College, Hartford, Connecticut.

74. Oliver Ellsworth to Caleb Strong, 25 October 1796 (quoting Matthew 16:18), Caleb Strong Papers, Forbes Library, Northampton, Massachusetts. This reference from the Book of Matthew to the gates of Hell was used by New England Calvinists to assure themselves and others that God was looking after their institutions. See, for example, C. Strong's Election Sermon (1799), 20 (Evans no. 36380) ("although God may suffer the powers of this world, to trample on his Church, for a season; yet He assures us, that "the gates of hell shall not prevail against it."); Hooker's Election Sermon (1805), 24 (Shaw-Shoemaker no. 8635). 75. Alexander Hamilton to James McHenry, 19 February 1800 (quoting Ellsworth), in The Papers of Alexander Hamilton, ed. Harold Syrett (New York: Columbia University Press, 1976), 24:237-38.

76. Oliver Ellsworth to Rufus King, 21 January 1801, Huntington Library, San Marino, California. 
tainly doomed as Sisyphus, Ellsworth was reaffirming that the federal government with Jefferson at the helm was part of God's plan. But God did not ordain Jefferson's election to the presidency as a reward. Instead Ellsworth now saw service in the federal government as a richly deserved punishment. From this viewpoint the United States Constitution was no longer a milestone on the direct path to graceful order. Rather, the federal government had become a dead end crafted by God to serve an exemplary purpose. Ellsworth was not utterly pessimistic about the federal government's chances of success, and he evidently believed that the experience of government under Thomas Jefferson might educate the people in the need for reform. ${ }^{77}$ But Ellsworth had become ill during his mission to France, and his faith in the federal government had already been shaken. Shortly before writing of Jefferson and Sisyphus, he resigned his chief justiceship, retired from national politics, and returned to his orderly and righteous state of Connecticut. ${ }^{78}$

\section{The Establishment of ReLigion}

The clearest example of the influence of New England Calvinism upon individuals' understanding of the common good is found in the contrasting attitudes of Thomas Jefferson and Ellsworth toward the state's support of religion. Connecticut had a longstanding symbiotic relationship between church and state. The Calvinist Clergy strongly supported state government from the pulpit, and the state levied a tax upon all citizens for the support of religion. These tax revenues went directly to ministers for the payment of their salaries and the support of church-run schools. ${ }^{79}$

At the very beginning of the nineteenth century, Connecticut's Baptists mounted a petition movement to challenge the state's fiscal support of religion. Without going into the details of the Baptists' petitions, their basic complaint was that although Connecticut's tax laws were superficially neutral, the laws in fact gave the Standing Order Calvinist churches a decided financial preference. In addition, the Baptists objected that the state's practice of collecting taxes from Baptists and turning the money over to Baptist ministers was particularly officious and pernicious. This practice was directly contrary to the

77. Ibid. Oliver Ellsworth to Rufus King, 24 January 1801, Huntington Library, San Marino, California; Oliver Ellsworth to Mrs. Ellsworth, 20 March 1802, Connecticut Historical Society, Hartford, Connecticut.

78. Oliver Ellsworth to John Adams, 16 October 1800, in Documentary History of the Supreme Court, 1:123.

79. See McLoughlin, New England Dissent, 2: ch. 47-50. 
Baptists' firm conviction that the state should not interfere with the relationship between a Baptist minister and his congregation.

Although the Baptists' petitions were directed to the state legislature, the Connecticut Baptists also sought assistance from President Thomas Jefferson. ${ }^{80}$ In reply, Jefferson offered moral support and coined his famous phrase "a wall of separation between church and state."8I In contrast the Connecticut legislature offered no support and instead appointed a select committee chaired by Ellsworth to consider the Baptists' petition. ${ }^{82}$

The appointment of Ellsworth was a shrewd choice. He was one of the most respected men (at least among the ruling Calvinists) in the state $e^{83}$ and a key member of the state's political power structure. ${ }^{84}$ In addition, he had a serious interest in religion and was quite orthodox in his views on the proper relationship between church and state. At his select committee's first meeting, he reaffirmed his support of Connecticut's establishment when he reportedly threw the Baptist petition under the table, put his foot on it, and declared, "This is where it belongs." 85

A key to understanding this seemingly overdetermined reaction is found in God's promise to his people that "kings shall be thy nursing father." 86 Connecticut Calvinists frequently described the righteous

80. Danbury Baptists Association to President Thomas Jefferson (Oct. 1801), quoted and discussed in William McLoughlin, New England Dissent, 1630-1833 (Boston, Mass: Harvard University Press, 1971), 2: 1004-05.

81. Thomas Jefferson to Nehemiah Dodge et al., 1 January 1802, reprinted in Thomas Jefferson, Writings (Library of America, 1984), 510.

82. McLoughlin, New England Dissent, 2: ch. 50.

83. See notes 2 and 7 and accompanying text.

84. See Noah Webster to Rufus King, 5 May 1806 (marginalia by King), in The Life and Correspondence of Rufus King, ed. Charles King (New York: Da Capo Press, 1971; originally published 1900), 4:515-16; Thomas Paine to Elisha Babcock, 10 October 1803, in Yale University Library Gazette 30 (1956): 97-98. At the time of his appointment he had over thirty years of government experience at local, state, and national levels.

85. Ellen Larned, History of Windham County, Connecticut (Worcester, Mass.: C. Hamilton, 1874), 296. Ellsworth was not necessarily angry with the Baptists who signed the petition. The state's leading Federalist newspaper explained, "That the Baptists, and many others, were duped by [the state's Jeffersonian Republicans who were] less honest, but more crafty than [the Baptists], no one who is acquainted with the subject can doubt." "Review of the Proceedings at last Session of the Legislative of this state," Connecticut Courant, 14 June 1802, 3. Accord, Connecticut Courant, 6 June 1804, 3; Connecticut Courant, 1 June 1803 , 3. Seven years earlier, the state's leading Calvinist minister had voiced this same idea that dishonest enemies of the Standing Order were using false claims of freedom of conscience to dupe honest citizens. See Timothy Dwight, "Extracts from Dr. Divight's Thanksgiving Sermon, continued," Connecticut Courant, 23 March 1795, 1.

86. Isaiah $49: 23$. This passage is perhaps the origin of Connecticut Calvinist's habit of using the word, king, as a generic word for ruler; see n. 40 . 
ruler as a "nursing father," 87 and this metaphor was part of Ellsworth's worldview. ${ }^{88}$ This paternalism turned the Baptists' petition into a child's insulting complaint about their nursing fathers' stewardship of the family - a violation of the child's filial duties. ${ }^{89}$

Consistent with this overtly paternalistic imagery, the righteous rulers had obligations to their family. In particular, "the ruler ought to be a nursing father to a religion, which is calculated to root out iniquity, and make men good citizens." 90 Given this assumption that rulers should support religion, the notion of a nursing father being neutral in religious matters was "absurd." 91 To the contrary, a righteous ruler had a positive duty to foster the Christian religion as a counter to man's natural depravity. ${ }^{92}$ Although the church was a beneficiary of this duty,

87. See, e.g., Bellamy's Election Sermon (1762), quoted in text accompanying n. 226; Backus's Election Sermon (1793), 22 (Evans no. 25130); Lee's Election Sermon (1795), 16 (Evans no. 28957); C. Strong's Election Sermon (1799), 17 (Evans no. 36380); Burmet's Election Sermon (1803), 28 (Shaw-Shoemaker no. 3919); Hooker's Election Sermon (1805), 17 (Shaw-Shoemaker no. 8635). See also Dana's Election Sermon (1779), 23-24 (Evans no. 16252). This paternalistic view of government also is found in the section of A Summary of Christian Doctrine that treats society as a family headed by a king; Summary of Christian Doctrine, ch. XX, para. 9.

88. For example, the upper house of the States' General Assembly was known officially as the Governor's Council but in informal conversation Ellsworth referred to the members as "the Fathers." Oliver Ellsworth to Mrs. Ellsworth, 30 May 1780, Oliver Ellsworth Papers, Connecticut Historical Society, Hartford, Connecticut (describing his recent election to the Council as giving him "a seat with the Fathers"), quoted in Delegates' Letters, 15:216 fn. 2. See also Dana's Election Sermon (1779), 35-36 (Evans no. 16252); Whitney's Election Sermon (1788), 29, 30 (Evans no. 21601); Robbins' Election Sermon (1789), 26, 30, 32-33 (Evans no. 22118).

89. See Summary of Christian Doctrine, ch. XX, para. 5: "Children [are obliged] to obey our parents in the Lord, to treat them with reverence; to give heed to their instructions; to follow their good examples; to cover their failings; to be true to their interests; to serve them faithfully; and to pray and cherish their declining years." "Inferiors" in society owed a similar duty of deference and obedience to their "superiors." Ibid., para. 7. See also n. 40 (Ellsworth notes the people's duty to "fear God and honor King").

90. Backus's Election Sermon (1793), 22 (Evans no. 25130). Accord, Lee's Election Sermon (1795), 16 (Evans no. 28957); C. Strong's Election Sermon (1799), 17 (Evans no. 36380); Bumet's Election Sermon (1803), 21-22 (Shaw-Shoemaker no. 3919); Hooker's Election Sermon (1805), 17 (Shaw-Shoemaker no. 8635).

91. Stone's Election Sermon (1792), 23 (Evans no. 24820). Accord, Trumbull's Election Sermon (1801), 23 (Shaw-Shoemaker no. 1440) ("the greatest quackery"). See also N. Strong's Election Sermon (1790), 17-18 (Evans no. 22913); Backus's Election Sermon (1793), 25 (Evans no. 25130); Burnet's Election Sermon (1803), 21 (Shaw-Shoemaker no. 3919). Indeed, some argued that for the civil government to be neutral on religious matters was an impossibility. C. Strong's Election Sermon (1799), 16 (Evans no. 36380), quoting Matthew 12:30 ("He that is not with me is against me."); Trumbull's Election Sermon (1801), 22 (Shaw-Shoemaker no. 1440).

92. N. Strong's Election Sermon (1790), 18-19 (Evans no. 22913); Dwight's Election Sermon (1791), i8 (Evans no. 23341); Backus's Election Sermon (1793), 21-22 (Evans no. 25130); Lee's Election Sermon (1795), 17-18 (Evans no. 28957); C. Strong's Election Sermon (1799), 17-18, 40 (Evans no. 36380); Burnet's Election Sermon (1803), 21 (Shaw-Shoe- 
Connecticut's clergy stressed the secular objects of the duty. One of Ellsworth's former ministers explained that "religion and its institutions are the best aid of government, by strengthening the ruler's hand, and making the subject faithful in his place, and obedient to the general laws." 93 The orthodox clergy recognized the general importance of separating church and state, 94 but they obviously were not strict separationists. As one minister frankly stated, "A sweet and harmonious union of church and state to promote the general good, must meet the full approbation of heaven."95

After a deliberation of less than a week, Ellsworth's committee issued a report that was published in the state's leading newspaper under his sole signature. ${ }^{96}$ Ellsworth followed the orthodox Calvinist line:

maker no. 3919); Hooker's Election Sermon (1805), 24 (Shaw-Shoemaker no. 8635). See also Dana's Election Sermon (1779), 25 (Evans no. 16252); Wetmore's Election Sermon (1773), 11-13 (Evans no. 13076).

93. N. Strong's Election Sermon (1790), 15 (Evans no. 22913). Accord, Devotion's Election Sermon (1777), 31 (Evans no. 15285) ("Arguments for religious establishments, should stand upon the ground of morality."); Stone's Election Sermon (1792), 23-26 (Evans no. 24820); Lee's Election Sermon (1795), 17-18 (Evans no. 28957) ("it is on political principles that such regulations [supporting religion] call for the civil ruler's support."); Trumbull's Election Sermon (1801), 21-22 (Shaw-Shoemaker no. 1440); Bumet's Election Sermon (1803), 21-22 (Shaw-Shoemaker no. 3919); Hooker's Election Sermon (1805), 24-28 (ShawShoemaker no. 8635). See also Backus's Election Sermon (1793), 25-26 (Evans no. 25130). Christianity also provided purely private secular benefits by "reconcil[ing] us to the interest of . . our neighbors." N. Strong's Election Sermon (1790), 17 (Evans no. 22913). Accord, Stone's Election Sermon (1792), 26 (Evans no. 24820); Burnet's Election Sermon (1803), 21-22 (Shaw-Shoemaker no. 3919); Hooker's Election Sermon (1805), 27-28 (Shaw-Shoemaker no. 8635). For an exception to these secular justifications, see C. Strong's Election Sermon (1799), 17-18, 40-41 (Evans no. 36380); see also Mss: Noah Webster, "Draft Report," 1802, Noah Webster Papers, New York Public Library. The Baptists thought these secular arguments were a sham; see John Leland, Van Tromp Lowering his Peak with a Broadside Containing a Plea for the Baptists of Connecticut (Danbury, Conn.: Stiles Nichols, 1806), 15-18.

94. Williams's Election Sermon (1780), 17-18 (Evans no. 17072); N. Strong's Election Sermon (1790), 15 (Evans no. 22913); Stone's Election Sermon (1792), 25 (Evans no. 24820); Backus's Election Sermon (1793), 22 (Evans no. 25130). In particular they objected to European establishments built on "laws prescribing faith, binding the conscience, and distinguishing by civil privilege the several classes of religions, or magistrates usurping the throne of the creator, and claiming the prerogatives of the supreme head of the church." Dwight's Election Sermon (1791), 18 (Evans no. 23341). Accord, Champion's Election Sermon (1776), 10-11 (Evans no. 14675); Williams's Election Sermon (1780), 27 (Evans no. 17072); (1780); Lee's Election Sermon (1795), 16-17 (Evans no. 28957); see also N. Strong's Election Sermon (1790), 16 (Evans no. 22913); Backus's Election Sermon (1793), 22-23 (Evans no. 25130); C. Strong's Election Sermon (1799), 40 (Evans no. 36380); Burnet's Election Sermon (1803), 22 (Shaw-Shoemaker no. 3919).

95. Ely's Election Sermon (1804), 34 (Shaw-Shoemaker no. 6243); see also Hooker's Election Sermon (1805), 24 (Shaw-Shoemaker no. 8635) (defending "a union of religion with civil government, as has always existed in this state.")

96. "Report of the Committee to whom was referred the Petition of Simeon Brown and others, complaining of certain existing Laws respecting the support of the Gospel" (1802), in 
"Institutions for the promotion of good morals, are [proper] objects of legislative provision and support: and among these, in the opinion of the committee, religious institutions are eminently useful and important." 97 To clarify his use of the phrase "good morals," Ellsworth emphasized that he was not talking about "speculative opinions in the theology and mere rites and modes of worship."98 Instead he endorsed state support of religious institutions because they are "wisely calculated to direct men to the performance of all the duties arising from their connection with each other, and to prevent or repress those evils which flow from unrestrained passion." 99

In addition to supporting the general idea of the state providing financial support to religion, Ellsworth squarely addressed the Baptists' central objection. He stated and restated that "every member of society should, in some way, contribute to the support of religious institutions." 100 He concluded his report with a clever lawyer's analogy comparing religious institutions to courts of justice and schools. All three institutions serve valuable secular functions. Therefore "no individual [should be] allowed to refuse his contribution, because he has no children to be instructed-no injuries to be redressed, or because he conscientiously believes those institutions useless."101

The Public Records of the State of Connecticut, ed. Christopher Collier (Hartford, Conn: Connecticut State Library, 1967), 11:371-74; Connecticut Courant, 7 June 1802, 2. The Select Committee consisted of eighteen legislators from the lower and upper houses of the General Assembly, including fifteen federalists; see McLoughlin, New England Dissent, 2:989. Undoubtly the report was the work of a small subcommittee. Ellsworth was the chairman and most influential member of the Committee (See McLoughlin, New England Dissent, 2:989), and the report was published in the state's leading newspaper under his sole signature. See n. 98 and accompanying text. Therefore, we may assume that he was an active participant in the drafting process and at the very least agreed with the ideas in the report.

97. "Ellsworth's Report," 373. Connecticut Federalists had advanced the same argument in the mid-1790s dispute over the proper use of the proceeds from the sale of the State's Western Reserve. See James Beasley, "Emerging Republicanism and the Standing Order: The Appropriation Act Controversy in Connecticut, 1793 to 1795," William and Mary Quarterly, 3rd ser. 29 (1972): 595, 609. Although this argument for the state support of religion frequently was made by New England Calvinists, the argument was not unique to Calvinists; see Linda Kerber, Federalists in Dissent (Ithaca, N.Y.: Cornell University Press, 1970), 20812 (using many Calvinist examples and a few non-Calvinists).

98. "Ellsworth's Report," 373. Accord, "Landholder VII."

99. "Ellsworth's Report," 373.

100. "Ellsworth's Report," 371, 373.

101. Ibid., 374. This secular analogy comparing religious institutions to courts and schools was not an original idea. See, for example, Noah Webster, A Collection of Essays and Fugitiv [sic] Writings (Worcester, Mass: Thomas \& Andrews, 1790), 345. See also Devotion's Election Sermon (1777), 31 (Evans no. 15285) (comparing religious institutions to schools). Noah Webster served on Ellsworth's Committee, and he probably had a hand in drafting the Committee's Report. McLoughlin, New England Dissent, 2:989. Nevertheless Webster probably was not the principal drafter. Webster's preliminary draft reached the same con- 


\section{CONCLUSION}

Calvinism clearly had a significant influence upon Americans of the founding era like Oliver Ellsworth, but to use Calvinism as the only lens for viewing the founding generation would grossly distort our vision. There were too many variables. Many Americans simply were not Calvinists, and even among the Calvinists there were significant doctrinal differences. Moreover, the intensity of personal faith varied from individual to individual. Even if we were to limit ourselves to a single individual, we might discover significant variations in faith over the course of the person's life. But to recognize these limitations is not to discard the model. These limitations are inherent in any model designed to provide insights into the dynamics of a pluralistic society.

The primary purpose of this essay has been merely to suggest that many participants in the founding of the American Republic were Calvinists who understood public life in terms of biblical revelation rather than secular virtue. Oliver Ellsworth can serve as an ideal-type for these righteous rulers. Religion may have had only a marginal significance for some members of the founding generation. Thomas Jefferson comes to mind. But religion was a core value for founders like Ellsworth who viewed themselves as righteous rulers. To the extent that we believe that pure ideas have a significant influence upon human conduct, Ellsworth's Calvinism undoubtedly had a significant influence upon his life. In any event, Ellsworth's Calvinism stands as an intricate and fully developed philosophical system that provides rich insights into his understanding of human society.

clusion as the "Ellsworth Report" but was significantly different in the presentation of supporting reasons. Mss: Noah Webster, "Draft Report," 1802, Noah Webster Papers, New York Public Library. 